\title{
PERAN MEDIA KOMUNIKASI DALAM MENINGKATKAN SRADDHA BHAKTI SISWA SEKOLAH MENENGAH ATAS DWIJENDRA DENPASAR
}

\author{
I Gusti Agus Wiranata $\underline{a}, 1$ \\ I Gusti Ngurah Sudiana a \\ I Ketut Sudarsana $\underline{a}$ \\ a Universitas Hindu Negeri I Gusti Bagus Sugriwa Denpasar \\ 1 Corresponding Author, email: aguswiranata@memorapro.com (Wiranata)
}

\section{ARTICLE INFO}

Article history:

Received: 10-07-2021

Revised:10-08-2021

Accepted: 15-09-2021

Published: 30-09-2021

Keywords:
Communication
Media, SMA
Dwijendra,
Sraddha Bhakti.
Community Radio,
Learning
Management
System

\begin{abstract}
Technological developments bring about major changes to communication patterns, including in the world of education. Compared to before, now students consisting of generation $Z$ are more interested in delivering dynamic materials that can be accessed from anywhere. Responding to these challenges, the Hindubased Dwijendra Denpasar High School (SMA) seeks to optimize the distribution of religious messages through the use of communication media. This study aims to analyze how far the communication media can play a role in improving students' sraddha bhakti. Researchers used three theories, namely Agenda Setting, Mathematical Communication, and Constructivism. This type of research is qualitative descriptive with a sociological approach. The research subjects were the school as communicators and students as communicants. Methods of data collection through participatory observation, structured interviews, document studies, literature studies, and online searches. The results showed that communication media consisting of Dwijendra Community Radio, audio-visual media, and Learning Management System (LMS) had an important role in the distribution of information related to sraddha bhakti. The media has advantages in terms of effectiveness, efficiency, concrete, and motivation. Barriers that arise in the role of communication media consist of technical barriers which include facilities and infrastructure, semantic barriers that include message content, and human barriers that arise from communication actors. The strategies applied by the school to improve the role of communication media include mapping problems, taking action on obstacles that occur, and optimizing the role of communication media using redundancy, canalizing, informative, educational, coercive, and persuasive methods. The evaluation shows that the role of communication media has positive implications for increasing students' knowledge, skills, and attitudes of Sraddha Bhakti.
\end{abstract}

\section{PENDAHULUAN}

Komunikasi merupakan salah satu aspek penting dalam kehidupan manusia. Melalui komunikasi, manusia dapat menyampaikan apa yang dipikirkannya kepada orang lain, baik secara langsung ataupun tidak langsung. Lunandi (1992: 37) menjelaskan, komunikasi merupakan kegiatan menyatakan suatu gagasan 
serta menerima umpan balik dengan cara menafsirkan kembali gagasan tersebut. Dalam perkembangannya, manusia membutuhkan sebuah sarana dalam upaya mengefektifkan proses komunikasi, memperkuat pemaknaan dan distribusi pesan. Manusia pun berupaya memanfaatkan bantuan media komunikasi.

Media komunikasi merupakan alat, sarana, atau sistem yang dapat membantu manusia dalam meneruskan informasi. Association of Education and Communication Technology (AECT) menambahkan, definisi media sebagai sebuah tatanan transmisi (bahan dan peralatan) yang tersedia untuk menyampaikan pesan tertentu (Sutirman, 2013: 15). Seiring waktu, manusia memosisikan media komunikasi menjadi begitu penting dalam proses berkomunikasi agar transformasi pesan menjadi efektif dan efisien.

Dalam dunia pendidikan, media komunikasi memiliki peran penting untuk pencapaian hasil yang diharapkan. Media memberi manfaat dalam menyalurkan pesan yang bersifat pengetahuan, keterampilan, dan sikap kepada siswa. Media juga dapat menstimulasi perhatian, perasaan, pilihan, serta kemauan anak didik. Sarana ini dapat secara sengaja membuat proses belajar-mengajar terjadi, bertujuan dan terkendali (Daryanto, 2010: 49). Dewasa ini, pemanfaatan media sebagai sarana pendidikan kerap dilakukan. Dahulu siswa lebih sering membaca buku fisik dan pembelajaran tatap muka untuk mendapat pengetahuan, tetapi saat ini siswa dimudahkan dengan mengakses e-learning melalui internet, penayangan video pembelajaran ataupun pemanfaatan media milik sekolah seperti radio komunitas, dan saluran-saluran lainnya.

Melihat pentingnya pemeranan media dalam penyebaran informasi dan pembentukan sikap, maka peran media komunikasi tak dapat dikesampingkan, termasuk di SMA Dwijendra Denpasar. Sekolah ini merupakan Sekolah
Menengah Atas yang menjunjung tinggi nilai sraddha bhakti dalam konsep pendidikannya. Penerapan sikap sraddha bhakti sejalan dengan cita-cita SMA Dwijendra Denpasar, yakni fokus pada pengembangan karakter siswa sesuai dengan Agama Hindu dan Budaya Bali yang tertuang dalam visi SMA Dwijendra, yang berbunyi:

SMA Dwijendra Denpasar berperan aktif dalam mengajegkan adat dan budaya Bali yang adi luhung berdasarkan sastra agama Hindu dan kemajuan ilmu pengetahuan di bidang teknologi dalam rangka mempersiapkan sumber daya manusia berkualitas memiliki kecakapan hidup dan siap bersaing pada masa globalisasi. Sehingga pemahaman dan pengamalan sraddha bhakti wajib dimiliki oleh setiap siswa. Sraddha dalam kamus sansekerta berarti kepercayaan atau kesetiaan sedangkan bhakti merupakan Wujud dan bentuk pengabdian berupa material maupun spiritual. Pengabdian secara material berupa sarana dan alat-alat persembahan, sedangkan secara spiritual melalui kesucian pikiran dan rohani yang tulus dalam memuliakan Tuhan (Subagiasta, 2015: 2). Dapat dikatakan bahwa, sraddha bhakti merupakan bentuk kepercayaan, kesetiaan, serta pengabdian ke hadapan Ida Sang Hyang Widhi Wasa melalui ajaran agama Hindu.

Saat ini, siswa SMA Dwijendra Denpasar terdiri dari golongan umur remaja yang sangat akrab dengan gadget, teknologi, dan multimedia. Golongan umur ini biasa disebut generasi Z, atau mereka yang lahir antara rentang tahun kelahiran 1998 sampai 2010. Generasi ini cenderung memiliki ketertarikan untuk mengakses informasi dengan cepat dan di mana saja melalui perangkat yang dimiliki. Grail Research (dalam Rastati 2018: 63) menjelaskan bahwa generasi Z memiliki karakteristik gemar terhadap teknologi, fleksibel, cerdas, berpikiran global dan menggunakan media dalam melakukan interaksi. Hal ini menjadi catatan dan 
tantangan tersendiri bagi pihak sekolah. Jika pemaparan materi pelajaran masih memakai cara konvensional dengan hanya mengandalkan tatap muka dan verbal, maka pelajaran agama Hindu akan sulit mendapat perhatian siswa. Untuk itu, guru Agama Hindu sebagai ujung tombak pembentukkan karakter siswa, berupaya mengemas materi sraddha bhakti dengan kreatif disesuaikan dengan karakter remaja yang aktif disertai kemudahan dalam mengaksesnya.

Penggunaan lebih dari satu saluran media komunikasi diharapkan dapat memberikan alternatif pilihan sesuai dengan karakter siswa yang beragam. Dalam penerapan di SMA Dwijendra Denpasar, terdapat saluran wajib dan saluran alternatif yang dapat diakses oleh siswa berdasarkan kebutuhan. Blumer dan Katz (dalam Nurudin 2003: 181) menyatakan bahwa, pengguna media memainkan peran penting untuk memutuskan pilihan dalam penggunaan media. Pengguna media merupakan pihak yang aktif dalam proses komunikasi, objek media ini berupaya mencari sumber media yang paling sesuai dalam usaha memenuhi kebutuhannya.

Beberapa pemanfaatan media komunikasi yang dilakukan SMA Dwijendra dalam meningkatkan sraddha bhakti siswa di lingkungan sekolah adalah pemanfaatan Radio Komunitas (Rakom) Dwijendra 107.7 FM, pemanfaatan media audio visual, serta pemanfaatan aplikasi belajar daring berupa Learning Management System (LMS).

Melihat upaya yang dilakukan SMA Dwijendra Denpasar dalam penggunaan media komunikasi, maka peneliti sangat tertarik untuk melihat lebih jauh bagaimana pemeranan media komunikasi di SMA Dwijendra Denpasar melalui penelitian yang berjudul "Peran Media Komunikasi dalam Meningkatkan Sraddha Bhakti Siswa Sekolah Menengah Atas Dwijendra Denpasar".
Adapun rumusan masalah dalam penelitian ini adalah: 1. Mengapa media komunikasi mempunyai peran penting dalam meningkatkan Sraddha Bhakti siswa SMA Dwijendra Denpasar? 2. Apa hambatan pemeranan media komunikasi yang dialami pihak sekolah dalam meningkatkan Sraddha Bhakti siswa SMA Dwijendra Denpasar?, 3. Bagaimana strategi pemeranan media komunikasi yang diterapkan pihak sekolah dalam meningkatkan Sraddha Bhakti siswa SMA Dwijendra Denpasar?

Penelitian ini dibagi menjadi dua konsep, yakni peran media komunikasi dan sraddha bhakti. Soekanto (2002: 243) menjelaskan, peran merupakan aspek dinamis dari sebuah status yang melekat terhadap hak dan kewajiban seseorang sesuai dengan fungsinya. Sedangkan Association of Education and Communication Technology (AECT) menjelaskan, definisi media sebagai sebuah tatanan transmisi (bahan dan peralatan) yang tersedia untuk menyampaikan pesan tertentu (Sutirman, 2013: 15). Lebih lanjut, pengertian komunikasi menurut Lunandi (1992: 37) adalah, kegiatan atau aktivitas dalam menyatakan sebuah ide atau gagasan serta menerima umpan balik dengan cara menafsirkan kembali gagasan dan pernyataan dari orang lain. Berdasarkan uraian tersebut, maka peran media komunikasi yang dimaksud adalah fungsi media sebagai sarana penghantar ide, gagasan, atau informasi dari komunikator ke pada komunikan

Secara etimologi kata sraddha berasal dari kata srat yang memiliki arti hati, dan dha berarti sesuatu. Kata sraddha sering dirangkaikan dengan dengan kata panca sehingga menjadi Panca Sraddha. Kata panca berarti lima, sedangkan sraddha berarti keyakinan/kepercayaan. Untuk pengertian bhakti, Madrasuta (2005: 116) menjelaskan, bhakti berasal dari akar kata bhaj, artinya 'membagi' atau 'setia' (to share, be loyal). Bhakti 
artinya tulus dalam pemujaan kepada Tuhan (istadewata). Jadi sraddha bhakti yang dimaksud adalah kepercayaan dan kesetian umat Hindu terhadap Ida Sanghyang Widhi Wasa yang diwujudkan dalam bentuk persembahan, persembahyangan, maupun pengamalan sikap kebajikan dalam keseharian kepada semua mahluk ciptaan Ida Sanghyang Widhi Wasa sebagai percikan kecil dari Beliau, sesuai dengan ajaran agama Hindu.

Landasan teori yang dipakai dalam penelitian ini terdiri dari tiga teori. Untuk menganalisa rumusan masalah pertama digunakan teori Agenda Setting. Teori ini pertama kali diperkenalkan oleh Maxwell McCombs dan Donald L. Shaw 1972, melalui artikel yang berjudul "The Agenda Setting Function of Mass Media" yang dipublikasikan di jurnal "Public Opinion Quaterly" (Vera, 2010: 113-114). Secara singkat, teori Agenda Setting menjelaskan bahwa media memiliki kekuatan untuk mengarahkan pada pengguna tentang apa yang harus dilakukan. Media memberikan agenda-agenda lewat penyebaran informasinya, sedangkan khalayak akan mengikutinya jika terpapar dengan intesitas tinggi.

Berikutnya, untuk menganalisa rumusan masalah kedua digunakan teori Matematikal Komunikasi. Teori Matematikal Komunikasi pertama kali dikenalkan oleh Claude Shannon dan Warren Weaver pada 1949 dalam buku The Mathematical Theory of Communication. Teori ini menjelaskan komunikasi sebagai sebuah fenomena mekanis, informatif, dan matematis. Penekanan penting dalam teori ini adalah adanya gangguan, yakni setiap rangsangan tambahan yang tidak dikehendaki (noise) hingga dapat mengganggu kecermatan pesan yang disampaikan. Gangguan ini selalu ada dalam saluran bersama pesan tersebut hingga diterima oleh komunikan (Mulyana, 2007: 149).

Terakhir, untuk menganalisa rumusan masalah ketiga digunakan teori
Konstruktivisme. Teori ini merupakan suatu teori pendekatan terhadap proses belajar. Pembelajaran yang memiliki karakteristik konstruktivisme menekankan terbangunnya pemahaman sendiri secara aktif, kreatif, dan produktif berdasarkan pengetahuan terdahulu serta pengalaman belajar yang bermakna (Muslich, 2007: 44). dapat disimpulkan bahwa teori konstruktivisme menekankan respons manusia terhadap permasalahan terdahulu yang memicu terbangunnya pemahaman untuk belajar dan menemukan sendiri strategi dalam mengatasi permasalahan sesuai dengan kompetensi, pengetahuan atau teknologi yang diperlukan guna pengembangan diri.

\section{METODE PENELITIAN}

Jenis penelitian yang digunakan dalam penelitian ini adalah deskriftif kualitatif dengan pendekatan sosiologis. Adapun lokasi penelitian yang diambil oleh penulis adalah Sekolah Menengah Atas Dwijendra Denpasar yang beralamat di Jalan Kamboja No. 17, Dangin Puri Kangin Kecamatan Denpasar Utara, Kota Denpasar, Bali 80236. Dipilihnya lokasi ini dikarenakan SMA dwijendra Denpasar merupakan salah satu sekolah menengah di Bali yang fokus pada pengembangan karakter siswa sesuai dengan Agama Hindu dan Budaya Bali. Di sekolah ini juga terdapat fasilitas komunikasi yang lengkap seperti stasiun radio, peralatan pemutar media yang mutakhir, serta pengembangan media pembelajaran jarak jauh yang sangat baik.

Pada penelitian ini, peneliti langsung sebagai inisiator dan pelaku utama dalam penelitian. Peneliti menggunakan bantuan instrumen berupa pedoman wawancara yang dilengkapi dengan perekam suara pada smartphone, dan pencatatan melalui buku. Pedoman wawancara dipergunakan untuk memperlancar komunikasi dengan para informan. Informan ditentukan secara purposive sampling yakni memilih informan dengan 
mempertimbangkan pengetahuan tentang masalah yang ditelaah yang dianggap dapat mewakili seluruh subjek penelitian. Informan terdiri dari Guru agama Hindu SMA Dwijendra Denpasar, Penanggung jawab siaran Radio Komunitas Dwijendra, Operator Laboratorium LMS, serta perwakilan siswa yang mempunyai kemampuan mengomunikasikan keadaan sekolah dengan baik.

Dalam penelitian ini, penulis menerapkan observasi partisipatif, yakni observasi yang dilakukan dengan cara ikut aktif dalam kegiatan yang diteliti. Selama observasi dilakukan, peneliti mendatangi langsung lokasi penelitian untuk mendapatkan gambaran yang sebenarnya yang terjadi. Teknik wawancara yang digunakan dalam penelitian ini adalah wawancara terstruktur dilengkapi dengan studi dokumen baik internal maupun eksternal, studi kepustakaan, serta penelusuran bahan online melalui website-website yang kredibel yang dapat mendukung data penelitian. Langkahlangkah analisis data dalam penelitian ini adalah reduksi data, klasifikasi data, display data, terakhir intepretasi dan pengambilan keputusan. Penyajian hasil analisis data dilakukan secara formal dan informal, yakni melalui gambar, tabel, dan narasi pendukung.

\section{HASIL DAN PEMBAHASAN}

\section{Peran Penting Media Komunikasi dalam Meningkatkan Sradha Bhakti Siswa}

SMA Dwijendra Denpasar adalah sekolah menengah atas yang memiliki visi melahirkan siswa berprestasi berlandaskan ajaran Agama Hindu. Oleh karena itu, Sraddha dan bhakti siswa perlu ditingkatkan karena selaras dengan apa yang dicita-citakan SMA Dwijendra Denpasar. Agar dapat mencapai tujuan yang diinginkan, maka mengomunikasikan pesan sraddha bhakti secara intens penting dilakukan. Pesan yang berulang akan menimbulkan ingatan kuat serta dapat mendorong motivasi terhadap perilaku.
Memerhatikan proses komunikasi yang berlangsung selama ini di SMA Dwijendra Denpasar, pihak sekolah merasa perlu meningkatkan dan mengoptimalisasi penggunaan media komunikasi agar siswa tak hanya mendapatkan informasi, namun juga memberikan nilai tambah dengan menyuguhkan informasi yang menarik untuk disimak. Penggunaan komunikasi verbal secara langsung diakui tidak cukup menarik minat siswa untuk semakin memahami ajaran agama Hindu. Tingkat penyerapan dan pemahaman yang rendah perlu diantisipasi dengan pengemasan materi yang atraktif melalui berbagai saluran yang dikembangkan oleh pihak sekolah. Hal tersebut senada seperti yang dijelaskan oleh Purnawati, guru agama Hindu SMA Dwijendra Denpasar (wawancara, 11 Mei 2020):

Melihat fenomena yang terjadi, bagaimana siswa lebih tertarik dengan suatu yang dinamis seperti gambar dan suara yang dikemas sedemikian rupa, maka kami merespons dengan memaksimalkan media komunikasi yang dimiliki oleh sekolah. Siswa pada masa sekarang cepat merasa bosan dengan pemaparan guru di depan kelas. Ini sangat berbeda dengan saat kita menyuguhkan video atau gambar-gambar menarik, mereka sangat antusias untuk memerhatikan. Hal yang sebelumnya sulit dinyatakan dengan verbal sekarang bisa diterjemahkan ke dalam visual. Proses belajarmengajar menjadi semakin efektif.

Kebutuhan tersebut membuat SMA Dwijendra Denpasar berupaya adaptif terhadap perkembangan zaman dan perubahan pola komunikasi yang terjadi di SMA Dwijendra Denpasar. Berdasarkan pertimbangan tersebut, pihak sekolah memaksimalkan pengembangan tiga media komunikasi utama yang dimiliki, yakni Radio Komunitas Dwijendra, pemanfaatan media audio visual, serta penggunaan Learning Management System (LMS).

Pemeranan Radio Komunitas dilakukan dengan memutar program yang bernafaskan 
agama Hindu. Beberapa mata acara yang memiliki nilai-nilai agama Hindu yakni program Tri Sandhya dan Dharma Wacana yang diputar setiap hari. Program Acara Tri Sandhya di putar tiga kali setiap pukul 06:00, 12:00, dan 18:00. Selepas Tri Sandhya pagi, pada pukul 06:05 acara radio dilanjutkan dengan acara Dharma Wacana. Acara ini merupakan program acara yang memuat cuplikan intisari ajaran-ajaran suci agama Hindu terutama yang berkaitan dengan tuntutan moral, budi pekerti, dan pencerahan. Dharma Wacana diputar pukul 06.05 pagi bertujuan agar dapat didengarkan oleh siswa dari rumah sambil bersiap ke sekolah. Acara Dharma Wacana dilakukan dengan dua cara yakni secara Live on Air dan tapping (direkam sebelumnya). Materi acara diisi oleh orangorang yang kompeten dalam bidang agama Hindu seperti guru agama Hindu yang berada di lingkungan Yayasan Dwijendra Denpasar, pemateri dari Kementrian agama Kanwil Bali, universitas Hindu, serta dari siswa berprestasi di lingkungan SMA Dwijendra Denpasar.

Berikutnya, pemeranan media audio visual dilakukan dengan mengimplementasikan pengetahuan sraddha bhakti melalui kemasan video maupun presentasi slide yang menarik, memanfaatkan fasilitas projektor maupun pengunggahan secara daring. Guru agama Hindu menyajikan tayangan yang terkait agar siswa lebih fokus memerhatikan dan dapat memahaminya dengan cepat. Guru agama Hindu juga menugaskan siswa untuk aktif membentuk kelompok-kelompok belajar dalam menerapkan pelaksanaan bhakti yang kemudian divisualkan. Beberapa penerapan sraddha bhakti yang disajikan melalui audio visual diantaranya pelajaran tentang esensi bhakti dan tutorial pembuatan sarana bhakti. Selain dipresentasikan, tugas audio visual siswa juga diunggah melalui Instagram masing-masing siswa, kemudian guru ditandai untuk dapat dinilai. Guru dan siswa berinteraksi melalui kolom komentar yang tersedia di Instagram. Tidak hanya diunggah, beberapa tugas dikirim melalui Whatsapp, email, serta menggunakan Google Drive untuk pengiriman berkas video yang berukuran besar. Fasilitas-fasilitas tersebut memudahkan guru dan siswa dalam berkomunikasi di luar jam sekolah.

Terakhir, pemeranan

Learning Management System (LMS). Pemeranan media belajar berbasis web ini mulai diterapkan oleh SMA Dwijendra Denpasar pada pertengahan tahun 2020, dalam rangka menjawab tantangan kebutuhan pembelajaran jarak jauh yang diberlakukan karena pembatasan sosial akibat pandemi. Untuk memaksimalkan hasil belajar, LMS dipadukan dengan layanan Google Meet. Dengan ini, siswa dan guru dapat berinteraksi sambil mengakses materi yang terdapat di LMS. Kegiatan belajar-mengajar dapat divirtualisasi dan diotomasi secara elektronik dengan medium ini. Melalui LMS, siswa dapat menyimak materi sraddha bhakti yang dikomunikasikan oleh guru agama Hindu menggunakan medium teks, audio, dan visual. Setelah siswa mengabsen, guru akan mengarahkan siswa untuk membaca materi sraddha bhakti yang dibagikan. Guru membuka sesi tanya jawab melalui Google Meet. Pertanyaan-pertanyaan yang muncul akan didiskusikan bersama. Siswa secara bergiliran mengutarakan jawaban yang dimiliki. Selepas sesi diskusi daring, siswa akan diberikan tugas untuk dikerjakan dirumah. Guru agama Hindu mewajibkan siswa agar membuat tugas terkait sraddha bhakti dengan tulis tangan, difoto, lalu diunggah melalui LMS. Ini sengaja dilakukan agar terdapat proses pembelajaran kreatif oleh siswa. Guru menganggap tugas ketik rawan kegiatan copy paste, sehingga tidak terjadi proses pembelajaran. Dari segi penilaian, LMS menawarkan kelebihan, dimana siswa dapat mengakses dan menyimpan nilai dari tugas yang dikerjakan. Hal ini dapat dijadikan parameter kemampuan oleh siswa bersangkutan. 
Media komunikasi di SMA Dwijendra Denpasar memberikan banyak keungulan sehingga pemeranannya dirasakan sangat penting dalam upaya peningkatan sraddha bhakti, diantaranya:

1. Efektif: penggunaan media komunikasi menawarkan kemudahan dan kelancaran dalam penyampaian informasi terkait sraddha bhakti di SMA Dwijendra Denpasar. Media-media tersebut mengatasi berbagai hambatan ruang dan waktu dalam upaya penyampaian materi. Guru tidak harus selalu bertatap muka dengan siswa dan tidak hanya terbatas di jam pelajaran sekolah. Media komunikasi seperti Rakom Dwijendra dan media komunikasi berbasis internet efektif meningkatkan pemahaman siswa terkait sraddha bhakti bahkan dari rumah siswa masing-masing.

2. Efisien: penggunaan media komunikasi memberikan keunggulan dalam mempercepat penyampaian materi sraddha bhakti. Materi terkait dapat diproduksi dan selanjutnya dapat diputar berulang-ulang sesuai kebutuhan. Guru tidak harus menyiapkan berkali-kali sarana dalam mambuat praktek kepada siswa. Sehingga banyak waktu yang dapat dihemat untuk pengembangan pengajaran berikutnya.

3. Konkret: berdasarkan bentuknya yang konkret penerapan media komunikasi terutama audio visual memudahkan siswa untuk memahami sesuatu yang abstrak. Dalam praktek berikutnya siswa dapat mengamati, meniru dan memahami dengan mudah penerapan sraddha bhakti karena audio visual memberikan kelebihan bentuk yang nyata.

4. Motivatif: penerapan media komunikasi dapat meningkatkan motivasi siswa untuk mempelajari ajaran agama Hindu. Hal tersebut karena media komunikasi menyuguhkan sesuatu yang dinamis dibandingkan pengajaran yang hanya mengandalkan verbal. Motivasi belajar yang tinggi memiliki potensi yang besar dalam keinginan siswa untuk mengimplementasikan dalam kehidupan sehari-hari.
Media-media yang terdapat di SMA Dwijendra Denpasar diintegrasikan dengan konsep konvergensi, yakni menggabungkan media-media yang ada untuk digunakan dan diarahkan ke dalam satu titik tujuan. Konvergensi berasal dari bahasa Inggris yaitu convergence. Kata konvergensi merujuk pada dua hal atau lebih bertemu dalam satu titik (Arismunandar, 2006: 1). Selain memang diwajibkan oleh pihak sekolah, dengan banyaknya saluran media maka siswa bisa menyesuaikan dan menentukan sendiri saluran mana yang dirasa tepat sesuai dengan ketertarikannya, sehingga bisa menghasilkan dampak yang maksimal.

Selain memanfaatkan banyak saluran, pihak SMA Dwijendra Denpasar juga memanfaatkan terpaan media yang tinggi. Terpaan media merupakan intensitas keadaan khalayak di mana terkena pesan-pesan yang disebarkan oleh suatu media. Terpaan media dapat diartikan sebagai kegiatan mendengar, melihat, dan membaca pesan-pesan media ataupun mempunyai pengalaman dan perhatian terhadap pesan tersebut yang dapat terjadi pada individu atau kelompok (Ardianto \& Erdinaya, 2005: 2). Semakin tinggi paparan siswa secara frekuensi (jumlah penayangan), durasi (waktu), dan atensi (perhatian) terhadap pesan sraddha bhakti, maka bisa dipastikan akan memberikan efek yang besar pula terhadap output.

Setelah saluran komunikasi melalui mediamedia yang dipergunakan dianggap berhasil, maka proses berikutnya adalah memusatkan pesan agar tercapai tujuan yang ingin dicapai oleh komunikator. Di sini dibutuhkan agenda dalam setiap pesan yang akan didistribusikan. Semua materi yang berkaitan dengan agama Hindu di SMA Dwijendra Denpasar selalu disisipi dengan kaidah sraddha bhakti, sehingga siswa yang mengakses informasi tersebut terbangun kesadaran bahwa sraddha bhakti adalah sesuatu yang penting dalam keseharian. Agenda setting 
menggambarkan kekuatan, pengaruh, media yang sangat kuat terhadap pembentukkan opini masyarakat karena media memberi tekanan pada suatu peristiwa maka media itu akan mempengaruhi khalayak untuk ikut mengganggap penting (Rakhmat, 1985).

Guru agama Hindu memberi penekanan secara terus-menerus tentang bagaimana pentingnya penerapan sraddha bhakti bagi siswa SMA Dwijendra Denpasar. Mulai dari pemahaman konsep, hingga praktik dalam sehari-hari. Dari hal-hal yang sederhana, seperti menjaga lingkungan, menghormati sesama warga sekolah, berbuat berdasarkan dharma, hingga penerapan bhakti seperti persembahyang bersama. Informasi tersebut selalu didistribusikan berulang-ulang hingga siswa menyadari dan mempercayai itu adalah sebuah kewajiban yang memang patut untuk dilaksanakan. Dorongan juga dilakukan dengan tugas-tugas praktik sehingga siswa menjadi fasih dalam pelaksanaan. Hal ini sesuai dengan yang dijelaskan oleh teori Agenda Setting, dimana teori ini memberikan penekanan pada suatu peristiwa yang dilakukan oleh media sehingga memengaruhi khalayak untuk menganggapnya penting. Secara singkat teori agenda setting mengatakan media selalu mengarahkan pada pengguna tentang apa yang harus dilakukan. Media memberikan agenda-agenda lewat penyebaran informasinya, sedangkan khalayak akan mengikutinya jika terpapar dengan intesitas tinggi.

\section{Hambatan Pemeranan Media Komunikasi yang Dialami Pihak Sekolah dalam Meningkatkan Sraddha Bhakti Siswa}

Dalam setiap kegiatan pasti dijumpai hambatan dalam pelaksanaanya, termasuk dalam berkomunikasi. Hambatan bisa diartikan sebuah halangan atau rintangan yang akan mengganggu sebuah proses. Dalam konteks komunikasi dikenal berbagai macam hambatan yang jika dibiarkan akan berdampak pada efektivitas pesan. Efektivitas pesan yang berkurang akan menghasilkan feedback yang tidak sesuai dengan apa yang diharapkan. Pada penerapan pemanfaatan media komunikasi di SMA Dwijendra Denpasar, walaupun pihak sekolah telah mengupayakan secara optimal, namun masih juga ditemui berbagai hambatan yang tidak dikehendaki. Wursanto (2005: 171) mengelompokkan hambatan komunikasi menjadi tiga macam, yaitu hambatan yang bersifat teknis, semantik, dan hambatan manusiawi. Hal tersebut sesuai dengan apa yang terjadi di SMA Dwijendra Denpasar.

Hambatan teknis kerap ditemui dan sangat mengganggu proses distribusi pesan di SMA Dwijendra Denpasar. Hambatan ini muncul dari sarana-prasarana atau media yang digunakan dan lebih bersifat teknikal. Hambatan komunikasi yang bersifat teknis ini mencakup ketersediaan fasilitas komunikasi, peralatan, teknologi, perijinan, dan jaringan yang dibutuhkan. Hal teknis tersebut termasuk dengan kesiapan orang-orang yang terkait untuk melakukan komunikasi menggunakan metode dan media komunikasi yang disepakati. Dalam pemanfaatan media komunikasi di SMA Dwijendra Denpasar, Hambatan teknis dikelompokan menjadi tiga, yakni (1) hambatan teknis pada Radio Komunitas Dwijendra, (2) Hambatan teknis pada penerapan media audio visual, dan (3) hambatan teknis pada Learning Management System (LMS).

1. Hambatan teknis pada Radio Komunitas Dwijendra, antara lain: (1) Rakom Dwijendra memiliki jangkauan daya pancar yang terbatas, yakni hanya 2,5 kilometer dari pusat pemancar. (2) Radio siaran analog yang memanfaatkan gelombang dalam transmisi siarannya memiliki sistem yang kompleks. (3) Pendengar tidak dapat dihitung secara realtime. (4) Transmisi analog sangat terpengaruh terhadap jarak dan cuaca.

2. Hambatan teknis media audio visual, antara lain: (1) kerusakan sangat sering terjadi akibat jumlah yang banyak disertai 
operasional pemakaian yang tinggi. (2) Kemampuan komunikator mengemas materi audio visual belum merata.

3. Hambatan teknis Learning Management System (LMS), antara lain: (1) Lokasi dan jaringan dari operator sangat berpengaruh terhadap kecepatan akses. (2) Pengunggahan dan penyimpanan data yang dilakukan setiap hari oleh banyak partisipan membuat server cepat mengalami kehabisan ruang penyimpanan. (3) Pada situasi yang sibuk dengan akses data yang tinggi, server dapat mengalami kelebihan beban operasi, sehingga server tidak dapat merespons permintaan login dari pengguna. (4) masih ditemui siswa yang mengalami kesulitan dalam memanfaatkan teknologi LMS.

Hambatan semantik merupakan jenis gangguan yang terjadi akibat kesalahpahaman dalam penggunaan bahasa maupun simbol (teks). Kesalahan ini mengakibatkan perubahan pada makna pesan yang ingin disampaikan oleh komunikator. Hambatan semantik muncul pada gangguan isi pesan yang membuat proses komunikasi menjadi berjalan tidak semestinya dan menghasilkan feedback yang tidak diinginkan. Gangguan semantik bila tidak dilakukan klarifikasi bahkan bisa menyebabkan perselisihan atau kesalahpahaman yang akan mengganggu proses belajar-mengajar. Dalam penerapan penggunaan media komunikasi di SMA Dwijendra Denpasar diupayakan meminimalisir gangguan jenis ini, namun gangguan semantik masih sering terjadi. Hambatan semantik pada penerapan pemanfaatan media komunikasi di SMA Dwijendra Denpasar dikelompokan menjadi dua berdasarkan jenis pesan, diantaranya: (1) Hambatan semantik verbal, dan (2) Hambatan semantik teks.

1. Hambatan semantik verbal, antara lain: (1) Kesalahan pengucapan oleh narasumber sering terjadi. (2) Istilah-istilah dalam materi agama merupakan materi yang tidak tidak dipergunakan sehari-hari, sehingga siswa sering susah menangkap istilah-istilah tersebut. (3) penggunaan kalimat yang panjang dan tidak efektif menyulitkan pendengar untuk menangkap maksud yang ingin disampaikan oleh komunikator.

2. Hambatan semantik teks, antara lain: (1) Kebiasaan penyingkatan teks pada Whatsapp. Hambatan ini biasanya muncul karena kebiasaan pengguna aplikasi menyingkat kata dengan teks-teks tertentu yang sangat rawan dalam penafsiran makna. (2) Kesalahan deskripsi unggahan. pada beberapa kasus, deskripsi yang dibubuhkan justru memberikan penafsiran berbeda. (3) Pada presentasi visual yang berbentuk grafis, sering terjadi typo atau saltik (kesalahan ketik).

Dibanding dua hambatan sebelumnya yang lebih ke teknis dan intepretasi pesan, hambatan manusiawi merujuk pada hambatan yang muncul oleh pelaku komunikasi, yakni komunikator dan komunikan. Hambatan ini muncul karena adanya faktor, emosi, prasangka pribadi, persepsi, kecakapan atau ketidakcakapan, dan kemampuan atau ketidakmampuan dan alat-alat pancaindera seseorang. Dalam Pemanfaatan media komunikasi di SMA dwijendra Denpasar hambatan ini berkontribusi besar dalam efektivitas pesan yang ingin disampaikan. Pihak sekolah telah meminimalisir hambatan ini dari sisi komunikator, sehingga fokus hambatan lebih ke siswa sebagai komunikan atau objek komunikasi. Pada proses yang berlangsung selama ini ditemukan beberapa hambatan manusiawi pada siswa Dwijendra Denpasar. Hal ini tetap terjadi walaupun pihak sekolah telah berusaha maksimal dalam meningkatkan atensi siswa untuk menyimak materi yang disebarkan melalui media komunikasi yang dikemas atraktif. Hal ini karena menyangkut personal dalam jumlah banyak maka agak sulit diatasi, namun tetap diusahakan untuk meningkatkan perhatian siswa. Beberapa hambatan manusiawi yang ditemukan, antara lain: (1) Hambatan psikologis. Pada siswa tertentu yang sedang 
mengalami permasalahan personal, efektivitas pesan menjadi menurun. (2) Motivasi diri rendah. Siswa yang mengalami kendala ini biasanya mengirim tugas tidak tepat waktu dan sekedar mengumpul. Jiwa kompetitif yang dimiliki tidak terasah. (3) Bosan dengan durasi lama. Hambatan ini dialami oleh sebagian besar siswa, mereka tidak bisa memerhatikan materi media visual yang diputar dengan durasi yang panjang, konsentrasi siswa sering terbelah, serta siswa cepat merasakan kelelahan

Hambatan pada proses komunikasi merupakan sesuatu yang wajar dan pasti terjadi. Hal ini disebabkan karena komunikasi merupakan proses yang kompleks dan melibatkan banyak hal di dalamnya. Mulai dari pelaku, isi pesan, saluran yang dipakai, serta feedback yang diharapkan. Dalam proses komunikasi, guru agama Hindu sebagai komunikator mengomunikasikan pesan terkait sraddha bhakti di SMA Dwijendra Denpasar. Pesan akan mengalami encoding atau pemrosesan sebelum dilanjutkan untuk didistribusikan. Dalam proses encoding tidak selalu berjalan baik, biasanya disini muncul hambatan yang bersifat semantik, atau hambatan dalam penyandian pesan. Hambatan berikutnya muncul saat pesan harus melewati saluran/media komunikasi yang digunakan oleh SMA Dwijendra Denpasar. Di dalam saluran komunikasi, pesan berpotensi mengalami gangguan teknis yang dapat menyebabkan distorsi terhadap pesan. Tahapan berikutnya, pesan akan sampai pada komunikan atau siswa SMA Dwijendra Denpasar. Potensi hambatan yang muncul pada tahap ini adalah hambatan dari perilaku siswa, sehingga dapat mengganggu proses encoding yang menghasilkan feedback berbeda dari yang diharapkan komunikator. Hal tersebut sesuai dengan Teori matematikal komunikasi yang dikenalkan oleh Claude Shannon dan Warren Weaver pada 1949 dalam buku The Mathematical Theory of
Communication. Penekanan penting dalam teori ini adalah adanya gangguan, yakni setiap rangsangan tambahan yang tidak dikehendaki (noise) yang dapat mengganggu kecermatan pesan yang disampaikan.

\section{Strategi Pemeranan Media Komunikasi yang Diterapkan Pihak Sekolah dalam Meningkatkan Sraddha Bhakti Siswa}

Strategi pemeranan media di SMA Dwijendra Denpasar berguna untuk mengatasi hambatan yang muncul dalam proses pemanfaatan media sebagai sarana pengantar pesan. Selain mengatasi hambatan, pihak sekolah juga menerapkan strategi untuk meningkatkan fungsi masing-masing media yang dimiliki agar semakin optimal. Effendy (1993: 301) menjelaskan, strategi adalah paduan dari perencanaan dengan manajemen komunikasi dalam mencapai suatu tujuan. Adapun penerapan strategi yang dilakukan di SMA Dwijendra Denpasar dalam pemeranan media komunikasi dilakukan dalam empat tahapan, yakni: Pemetaan masalah, tindakan mengatasi hambatan yang terjadi, strategi meningkatkan peran media komunikasi, dan evaluasi pemeranan media komunikasi.

Pemetaan masalah perlu dilakukan Sebelum menentukan strategi apa yang tepat untuk diterapkan. Dengan demikian, strategi yang dibentuk benar-benar tepat sasaran sehingga dapat memaksimalkan peran media dalam mendistribusikan pesan sraddha bhakti di lingkungan SMA Dwijendra Denpasar. Langkah pertama yang dilakukan adalah mendefinisikan masalah atau peluang. Pada tahap ini, pihak sekolah melakukan analisis situasi dengan menyelidiki dan memantau pengetahuan, opini, sikap, dan perilaku siswa yang intens mengakses media komunikasi di sekolah. Dalam hal ini pihak sekolah menggunakan analisis SWOT (strengthts, weakness, opportunities, dan threats) untuk mengetahui keadaan yang terjadi. Berikutnya, dilakukan perencanaan dan 
pemrograman. Informasi yang dikumpulkan melalui langkah pertama digunakan untuk membuat keputusan-keputusan yang strategis. Langkah-langkah tersebut berkelanjutan, bersifat siklis, dan diaplikasikan dalam pengaturan yang dinamis.

Langkah selanjutnya adalah tindakan mengatasi hambatan yang terjadi. Data-data yang didapat dari langkah sebelumnya dianalisa dan dicarikan solusi melalui strategi-strategi yang terukur, di antaranya: strategi yang diterapkan dalam mengatasi hambatan teknis pada Radio Komunitas Dwijendra, adalah: (1) Hambatan daya jangkau siaran yang terbatas, penghitungan pendengar secara realtime, dan gangguan transmisi diatasi dengan pengembangan sistem radio streaming. Sistem ini akan membantu distribusi siaran Dharma Wacana ke seluruh dunia tanpa batasan jarak. Sistem ini pun menawarkan fasilitas untuk memantau jumlah pendengar yang mengakses siaran radio saat pada saat on air. Gangguan transmisi yang diakibatkan oleh jarak dan cuaca tak ada lagi karena sistem streaming tidak mengandalkan panjang gelombang yang rentan terhadap gangguan eksternal. (2) Hambatan pada pemeliharaan peralatan radio yang rumit dan mahal diatasi dengan perekrutan tenaga teknis professional, sehingga alat akan terpelihara dengan baik. Dengan pemeliharaan berkala oleh tenaga professional maka potensi kerusakan pun akan dapat ditekan.

Strategi yang diterapkan dalam mengatasi hambatan teknis pada pemanfaatan media audio visual, adalah: (1) Hambatan sering rusaknya sarana pendukung, seperti projektor dan speaker yang mati diatasi dengan pemeliharaan berkala dan pengawasan yang ketat terhadap penggunaan. Untuk speaker yang beser atau mati, pengguna akan diarahkan untuk tidak memaksakan mengencangkan volume sampai maksimal. (2) Hambatan pada kemampuan guru mengemas materi audio visual belum merata diatasi dengan memberikan diklat perancangan grafis sederhana kepada setiap pengajar.

Strategi yang diterapkan dalam mengatasi hambatan teknis pada Learning Management System (LMS), adalah: (1) Hambatan pada jaringan internet yang tidak stabil diatasi dengan meningkatkan kualitas jaringan dengan memilih operator yang sesuai dengan lokasi sekolah. (2) Hambatan pada ruang penyimpanan dan server timeout, diupayakan dengan pemantauan berkala kondisi server, serta menyiapkan beberapa hardrive dengan ruang penyimpanan tinggi. (3) Keterampilan siswa mempergunakan teknologi belum merata diatasi dengan memetakan kemampuan masing-masing siswa, kemudian dibentuk kelompok-kelompok belajar. Siswa yang fasih dengan teknologi dan multimedia akan dikelompokkan dengan siswa yang memiliki kemampuan kurang.

Selain strategi mengatasi hambatan teknis, SMA Dwijendra juga menerapkan strategi dalam mengatasi hambatan semantik yang terjadi akibat kesalahpahaman dalam menangkap pesan, baik berupa verbal maupun teks. Adapun strategi yang diterapkan dalam mengatasi hambatan semantik verbal adalah: (1) Hambatan pada kesalahan pengucapan dan penggunaan kalimat tidak efektif diatasi dengan lebih mematangkan tahapan pra-produksi atau perencanaan. (2) Hambatan pada istilah rumit yang sulit dipahami, diatasi dengan menghindari istilah tersebut. Jika memang harus dipakai, dipastikan untuk dibahas pada saat sessi tatap muka agar siswa dapat memahami istilah yang dimaksud. (3) Kesalahan narasi pada video dan kesalahan teks pada presentasi visual diatasi dengan menerapkan prinsip kehati-hatian. Selalu mengecek kembali setiap materi yang akan dipublikasikan. Kroscek dilakukan juga oleh pihak lain agar memperkecil kemungkinan kesalahan.

Strategi yang diterapkan dalam mengatasi hambatan media komunikasi berbasis teks 
adalah dengan mengajak partisipan pada grup untuk mengurangi atau menghindari penyingkatan teks yang tidak perlu. Membiasakan siswa untuk mengetik sesuai kaidah penggunaan standar serta meningkatkan literasi. Peningkatan dilakukan dengan selalu mengoreksi hasil penulisan siswa.

Berbeda dengan dua strategi sebelumnya yang lebih ke teknis dan intepretasi pesan, strategi dalam mengatasi hambatan manusiawi lebih personal dan persuasif dengan melibatkan wali kelas, guru BK, dan wakasek kesiswaan. Hal tersebut dilakukan karena hambatan ini muncul dari pelaku komunikasi itu sendiri. Adapun strategi yang diterapkan dalam mengatasi hambatan manusiawi, antara lain: (1) Strategi dalam mengatasi hambatan psikologis dengan memberikan bimbingan dan konseling terhadap siswa yang bermasalah. Dengan demikian, siswa dapat mengeluarkan unek-uneknya. Diharapkan berikutnya saat perasaan siswa lebih baik, maka proses komunikasi dalam pembelajaran kembali normal. (2) Hambatan motivasi rendah diatasi dengan mengadakan pendidikan dengan konsep guru sekawan, yakni siswa bergiliran menjadi guru di depan kelas. Dengan konsep ini siswa diharapkan termotivasi untuk tampil maksimal di depan teman-temannya. (3) Siswa mengalami kebosanan di tengah penayangan diatasi dengan menjeda materi pada waktu-waktu tertentu, kemudian diputarkan sesuatu yang menarik perhatian seperti lagu-lagu dharma. Jika dirasa cukup, guru kembali memutarkan materi penayangan yang dijeda sebelumnya.

Strategi berikutnya, meningkatkan pemeranan media komunikasi yang dilakukan dengan enam metode, dua berdasarkan pelaksanaanya dan empat berdasarkan isinya. Metode komunikasi berdasarkan pelaksanaanya, antara lain: (1) Metode redundancy. Metode ini menerapkan cara pengulangan pesan berkali-kali untuk memengaruhi siswa. Intensitas pesan sraddha bhakti yang tinggi dapat menarik perhatian sekaligus menanamkan ingatan ke pada siswa. (2) Metode canalyzing. Pada metode ini komunikator atau pihak sekolah menyediakan berbagai saluran komunikasi, sehingga siswa dapat mengakses pesan sesuai dengan kebutuhan, kepribadian, dan kesenangan, serta motif masing-masing.

Sedangkan penerapan metode berdasarkan isinya, antara lain: (1) Metode informatif. Dalam dunia komunikasi massa dikenal jenis pesan yang informatif. Jenis pesan ini biasanya memengaruhi khalayak dengan memberi penerangan terhadap sesuatu pembahasan. Di SMA Dwijendra, materi sraddha bhakti dikemas dalam bentuk program radio. (2) Metode edukatif. Pada metode ini, materi sraddha bhakti dikemas dalam bentuk pesan yang merangkum fakta dan pengalaman. Sumber-sumber valid dicantumkan sehingga siswa mendapat edukasi dan mempercayai kesahihan pesan. (3) Metode koersif. Metode koersif adalah metode memengaruhi khalayak dengan cara memaksa. Metode ini sangat jarang dipakai di SMA Dwijendra Denpasar. Namun, pada sedikit kasus metode ini cukup efektif digunakan, terutama pada siswa yang memiliki masalah terhadap disiplin dan motivasi belajar yang lemah. (4) Metode persuasif. Metode ini diterapkan dengan mengajak siswa berkolaborasi terhadap pembahasan materi sraddha bhakti. Pada program Dharma Wacana di Radio Komunitas Dwijendra, siswa yang dianggap berprestasi ikut diberikan kesempatan untuk menjadi pembicara sehingga siswa yang lain menjadi termotivasi.

Langkah terakhir adalah evaluasi pemeranan media komunikasi dengan melaksanakan penilaian berkala terhadap implementasi strategi yang telah diterapkan. Penyesuaian terus dilakukan berdasarkan hasil pengamatan komunikator (guru) atau temuan terbaru dan feedback yang didapat dari 
komunikan (siswa) mengenai bagaimana efektivitas peran media komunikasi yang telah diterapkan. Effendy (1989: 62) menyatakan, komunikasi yang efektif adalah komunikasi yang menimbulkan efek tertentu sesuai dengan tujuan yang diharapkan oleh komunikator.

Observasi pendidik terhadap sikap bhakti siswa menunjukkan hasil yang positif sesuai dengan tujuan yang diharapkan. Ini dapat terlihat dari beberapa penerapan Nawa Widha Bhakti siswa di sekolah yang erat kaitannya dengan sraddha bhakti, seperti: (1) Penerapan srawanam, yaitu sebagian besar siswa selalu mendengarkan dengan baik saat guru memberikan pelajaran/nasehat. (2) Penerapan kirthanam, yakni partisipasi siswa dalam melantunkan kidung suci saat hari raya besar agama Hindu yang dilaksanakan di sekolah seperti saraswati. (3) Penerapan padasewanam, yakni siswa selalu memberikan salam saat berpapasan dengan guru ataupun yang lebih tua di sekolah. (4) penerapan sukhyanam, terlihat dari harmonisnya hubungan horisontal di sekolah. Sangat jarang terjadi konflik antar siswa. (5) Penerapan arcanam terlihat dari tingginya antusias siswa untuk bersembahyang perseorangan/kelompok di padmasana sekolah setiap pagi sebelum jam pelajaran dimulai. Hal ini diakui sangat dipengaruhi oleh pesan yang disampaikan melalui media komunikasi yang diterapkan di sekolah.

Berikutnya, penilaian pengetahuan terhadap sraddha bhakti ditujukkan untuk mengukur kemampuan siswa secara faktual, konseptual, prosedural, dan metakognitif. Juga untuk melihat kecakapan berpikir siswa tingkat rendah hingga tinggi. Penilaian ini bertujuan untuk ketercapaian KD pada K-13 yang dilakukan oleh guru agama Hindu. Guru agama Hindu menetapkan teknik penilaian dengan menyesuaikan karakteristik dan kompetensi yang akan dinilai. Hasil menunjukkan bahwa nilai rata-rata pengetahuan siswa SMA
Dwijendra Denpasar berada di atas Kriteria Ketuntasan Minimum (KKM) yang ditentukan. Pada kelas XI MIPA I terlihat bahwa nilai ratarata terkecil berada pada angka 83, ini di atas dari nilai KKM kelas XI yang ditentukan di SMA Dwijendra Denpasar, yakni 79.

Terakhir aspek keterampilan. Penilaian pada aspek ini ditekankan pada kemampuan siswa SMA Dwijendra dalam melaksanakan tugas agama Hindu terkait materi sraddha bhakti. Pada penjelasan Kurikulum 2013, keterampilan meliputi dua hal, yakni keterampilan yang bersifat abstrak (berpikir) dan keterampilan yang bersifat konkret (kinestetik). Penilaian kompetensi ini menunjukkan peningkatan hasil yang signifikan dari sisi antusiasme siswa untuk membuat tugas dan kreativitas siswa dalam mengemasnya. Data pengumpulan tugas terekam dalam system LMS yang dapat dijadikan acuan untuk penilaian. Selain membuat video, guru agama Hindu juga memberikan tugas keterampilan kepada siswa berupa pembuatan poster, dan penerapan bhakti lainnya ke dalam medium-medium kreatif yang dapat merangsang ketertarikan siswa dalam mengerjakan.

Pemaparan di atas menunjukkan, pemilihan strategi yang tepat dapat memecahkan masalah yang terjadi dan meningkatkan peluang dalam merealisasikan tujuan akhir yang ingin dicapai. SMA Dwijendra secara aktif mengembangkan berbagai strategi dalam penggunaan media komunikasi agar terjadi peningkatan sraddha bhakti dalam diri siswa. Strategi dapat dirumuskan berdasarkan hambatan-hambatan yang ditemui. Hambatan dipelajari dan dicarikan solusi sehingga peran media semakin optimal dalam meningkatkan sikap, pengetahuan, serta keterampilan siswa dalam pelajaran agama Hindu, spesifiknya nilainilai sraddha bhakti. Hal tersebut sesuai dengan penjelasan teori konstruktivisme, dimana teori ini menekankan respons manusia terhadap 
permasalahan terdahulu yang memicu terbangunnya pemahaman untuk belajar dan menemukan sendiri strategi dalam mengatasi permasalahan sesuai dengan kompetensi, pengetahuan atau teknologi yang diperlukan guna pengembangan diri dalam mencapai tujuan.

\section{SIMPULAN}

Berdasarkan analisis dan penyajian data pada uraian di atas, maka terdapat beberapa hal yang menjadi simpulan terkait penelitian Peran Media Komunikasi dalam Meningkatkan Sraddha Bhakti Siswa SMA Dwijendra Denpasar, di antaranya:

Media komunikasi memiliki peran penting karena memberikan kemudahan dalam pendistribusian pesan terkait sraddha bhakti di SMA Dwijendra Denpasar. Di samping itu, Pemeranan media juga memberikan keunggulan dari sisi efektivitas pesan yang tinggi, efisien dalam penerapan, mudah diresapi melalui bentuk yang konkret, serta motivatif untuk meningkatkan atensi siswa dalam menyimak materi. Media komunikasi yang terdiri dari Radio Komunitas Dwijendra, media audio visual, serta pembelajaran daring Learning Management System (LMS) ini diintegrasikan dengan mengusung konsep konvergensi, yakni pemusatan tujuan dengan satu agenda yang sama. Melalui keunggulan tersebut, pihak sekolah lebih memiliki keleluasaan dalam menanamkan pemahaman dan kepercayaan terhadap ajaran sraddha bhakti ke pada siswa.

Hambatan pemeranan media komunikasi yang dialami pihak sekolah dalam meningkatkan sraddha bhakti siswa di SMA Dwijendra Denpasar dikelompokkan menjadi tiga, yakni: (1) Hambatan teknis, gangguan yang muncul dari sarana-prasarana yang digunakan dan bersifat teknikal. Hambatan teknis yang ditemui dalam pemeranan media komunikasi di SMA Dwijendra Denpasar adalah, masalah daya pancar, kerusakan alat, server, penguasaan teknis, dan jaringan internet. (2) Hambatan semantik, jenis gangguan yang terjadi akibat kesalahan dalam pemaknaan pesan. Hambatan semantik yang terjadi dalam pemeranan media komunikasi di SMA Dwijendra Denpasar seperti kesalahan pengucapan, penggunaan istilah rumit sehingga sulit ditangkap, kesalahan ketik, dan penyingkatan teks. (3) Hambatan manusiawi, merupakan jenis gangguan yang muncul oleh pelaku komunikasi. Hambatan ini muncul karena adanya faktor, emosi, prasangka, kecakapan, dan kemampuan alat-alat pancaindera pelaku komunikasi. Hambatan manusiawi yang ditemui pada siswa SMA Dwijendra Denpasar seperti permasalahan psikologi, motivasi yang rendah, dan permasalahan daya simak siswa dalam jangka waktu yang lama.

Strategi pemeranan media komunikasi yang diterapkan pihak sekolah dalam meningkatkan sraddha bhakti siswa SMA Dwijendra Denpasar dilakukan dengan empat tahapan, yakni: (1) Diawali dengan pemetaan masalah dan target yang ingin dicapai, hal ini dilakukan dengan cara mendefinisikan masalah atau peluang sehingga dapat ditindak-lanjuti dengan penerapan strategi yang sesuai dengan dibutuhkan. (2) Menjawab satu persatu permasalahan dengan solusi, seperti permasalahan teknis yang diatasi dengan peningkatan kualitas sarana dan prasarana, permasalahan semantik diatasi dengan peningkatan kualitas isi pesan, dan permasalahan manusiawi diatasi dengan melakukan tindakan persuasif bekerjasama dengan wali kelas, guru BK, dan wakasek kesiswaan. (3) Peningkatan peran media komunikasi, dilakukan dengan pengaplikasian metode redundancy, canalizing, informatif, edukatif, koersif, dan persuasif pada pesan yang disebarkan. (4) Terakhir, dilakukan tahap evaluasi. Evaluasi menunjukkan, pemeranan media komunikasi memberi implikasi positif 
terhadap peningkatan sraddha bhakti siswa. Hal tersebut dapat dilihat dari sikap siswa melalui penerapan Nawa Wida Bhakti di lingkungan sekolah, nilai pengetahuan agama Hindu siswa di atas Kriteria Ketuntasan Minimal yang ditentukan, serta keterampilan dan kreativitas siswa dalam pembuatan tugas sraddha bhakti yang meningkat.

\section{SARAN}

Dari pemaparan di atas, maka dapat diuraikan beberapa saran yang kiranya bisa memberikan kontribusi positif terhadap pemanfaatan peran media komunikasi dalam meningkatkan sraddha bhakti siswa di Sekolah Menengah Atas dwijendra Denpasar, antara lain:

Saran terhadap Yayasan pengelola SMA Dwijendra Denpasar. Melihat pesatnya perkembangan teknologi media komunikasi dan efektifitasnya yang besar, maka ada baiknya pihak Yayasan meningkatkan dukungan, baik dari segi finansial melalui sarana-dan prasarana penunjang, maupun peningkatan sumber daya manusia yang peduli terhadap pembaruanpembaruan terkini.

Saran terhadap Guru Agama Hindu SMA Dwijendra Denpasar. Guru-guru terutama guru agama Hindu meningkatkan kemampuan operasional teknis maupun peningkatan materi yang disesuaikan dengan perkembangan komunikasi yang sangat pesat. Mengurangi penggunaan konvensional dan beralih menggunakan media komunikasi berbasis teknologi yang terbaru.

Saran terhadap Siswa SMA Dwijendra Denpasar. Lebih peduli terhadap pelajaran Agama Hindu terkait materi sraddha bhakti yang disuguhkan melalui pemanfaatan media komunikasi milik sekolah dengan berbagai macam bentuknya.

\section{DAFTAR PUSTAKA}

Ardianto, Elvinaro dan Erdinaya, Lukiati Komala. 2005. Komunikasi Massa Suatu
Pengantar. Bandung: PT Remaja Rosdakarya.

Arismunandar. 2006. Manajemen Pendidikan (Peluang dan Tantangan). Makasar: State

Daryanto. 2010. Media pembelajaran. Yogyakarta: Gava Media.

Effendy, Onong Uchjana. 1990. Ilmu Komunikasi Teori dan Praktek. Bandung: PT. Remaja

Lunandi, A.G. 1992. Meningkatkan Efektifitas Komunikasi Antar Pribadi. Yogyakarta: Kanisius.

Mulyana, Deddy. 2007. Ilmu Komunikasi: Suatu Pengantar. Bandung: Remaja Rosdakarya.

Muslich, Mansur. 2007. KTSP. Pembelajaran Berbasis Kompetensi dan Kontekstual. Panduan

Nurudin, 2003. Komunikasi Massa, Yogyakarta: Pustaka Pelajar.

Rakhmat, Jalaludin. 2010. Psikologi komunikasi. Bandung: Remaja Rosdakarya.

Rastati, Ranny. 2018. Media Literasi Bagi Digital Natives: Perspektif Generasi Z di Jakarta. Jurnal Teknologi Pendidikan. Jakarta.

Soekanto, Soerjono. 2002. Teori Peranan. Jakarta: Bumi Aksara.

Subagiasta, I Ketut. 2008. Sraddha dan Bhakti. Surabaya: Paramita.

Sutirman, 2013. Media \& Model-model Pembelajaran Inovatif. Yogyakarta: Graha Ilmu

Vera, Nawiroh. 2014. Semiotika dalam Riset Komunikasi. Bogor: Ghalia Indonesia.

Wursanto. 2005. Dasar-Dasar Ilmu Organisasi. Yogyakarta : Andi.

Internet:

Yayasan Dwijendra. 2019. Visi Misi SMA Dwijendra Denpasar [online]. Diakses dari https://bit.ly/38K5PsN, tanggal 16 Nopember 2019.

Jdih Kominfo. 2012. Peraturan Menteri Komunikasi dan Informatika Nomor 39 Tahun 2012 tanggal 4 Oktober 2012 [online]. Diakses dari shorturl.at/cjFM5, tanggal 20 Juni 2020. 